\title{
FERRAZ, Salma. Em nome do homem. Rio de Janeiro: Sette Letras, 1999.
}

\author{
Celso Leopoldo Pagnan ${ }^{l}$ \\ Universidade Estadual de São Paulo/Assis
}

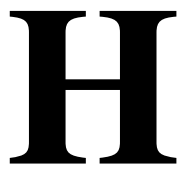

á certo discurso, de senso comum, que apregoa a idéia segundo a qual o crítico é um artista que não deu certo, e por isto mesmo passa a criticar, destacando mais os defeitos que explicitando as qualidades da obra de arte. No entanto, se atentarmos um pouco veremos que se trata de um argumento falacioso, afinal, muitos artistas foram, eles também, críticos. Só para citar alguns: Machado de Assis, José de Alencar, Mário de Andrade, Silviano Santiago.

Fazendo esse mesmo percurso, do campo da crítica para o campo da ficção, surge a escritora Salma Ferraz. Doutoranda pela Unesp, autora de diversos trabalhos críticos, a ensaísta apresenta o seu primeiro livro de contos publicado pela editora Sette Letras Em nome do bomem que traz, além do conto que dá título ao livro, outros nove.

Neste conto, cuja enredo se desenrola em um Seminário Teológico, há uma passagem que pode servir para ilustrar a idéia presente nos demais: "Pensava em Lutero, em Calvino, tanto sofrimento, tanta luta, tantos séculos de sangue, tudo para acabar ali resumido num único ato: teólogos trapaceando a Telesp, através de um orelhão escangalhado em pleno Shabat judeu." Ou seja, toda possibilidade de transcendência se anula diante da presença do cotidiano, absolutamente em nada sagrado. São as situações do cotidiano que parecem dar sustentação às personagens, aos

\footnotetext{
${ }^{1}$ Doutorando em Literaturas de língua portuguesa - Unesp/Assis.
} 
homens ali retratados. É um cotidiano marcadamente presente, o cotidiano das roupas, da música, dos bairros paulistas, curitibanos, rondonienses. Há enfim, nos contos, uma preocupação em narrar os vestígios do dia, os vestígios do homem comum.

Outra marca da narrativa de Salma Ferraz é o constante dialogismo, a constante intertextualidade estabelecida não só com os textos de uma tradição cultural vista como superior, mas também com textos aos quais se atribuem importância menor: músicas sertanejas, pagode, alguns filmes hollywodianos, como A mão que balança o berço, ou mesmo com o cult Blade Runner, dois filmes que servem de título a dois dos contos da autora paranaense. Na verdade, esta prática está na base do seu pensamento crítico, afinal como pensadora da literatura e da cultura não se atém apenas aos chamados grandes bens culturais, mas dirige seus estudos críticos para compreender as razões da indústria cultural. Além de ensaios sobre Fernando Pessoa, Eça de Queirós, Machado de Assis ( A Sagrada Luxúria de Criar - Porto Alegre: Edipuc,
1999), Raimundo Caruso (Noturno 1894 - Na Terceira Margem da História - Blumenau: Furb, 1999) e o prêmio Nobel de Literatura José Saramago (O Quinto Evangelista - Brasília; UNB, 1999, também se dedicou a pesquisar a cultura de massa. No Jeitinho brasileiro de Sherlock Holmes - Blumenau: Furb, 1998, procurou analisar os meandros da composição do romance $O$ Xangô de Baker Street, de Jô Soares. Em O rei leão e memória do mundo analisou a intertextualidade com as obras clássicas da literatura universal e a problemática do bem e do mal da produção cinematográfica dos Estúdios Walt Disney, O Rei Leão.

A contista, tanto no depoimento, que serve de prefácio, quanto nas epígafes revela o próprio processo criativo. Ainda que não se deseje aqui contrariar os estudos de Eliot, segundo os quais vale menos a biografia de um autor que a obra que produz, não há como negar a importância da vivência de autora na construção das estórias e das personagens. Rosvita de Askenville e O Santo do Posso nasceram certamente das percepções da escritora quando de sua estada 
em Rondônia como professora universitária. Em nome do homem traz igualmente as marcas dos estudos teológicos que fez num seminário protestante em São Paulo. Não significa, entretanto, que a Salma Ferraz empírica esteja inteiramente presente na vida das personagens, mas sim, que o real é ponto de partida para a ficção o que acaba por inscrever a escritora em uma grande tradição realista. Para ilustrar o nosso pensamento, citamos um trecho de uma das epígrafes de abertura dos contos: "Os meus livros (...) são e não são autobiográficos. São autobiografias em segundo grau, ou autobiografias da minha fantasia."

No retrato do cotidiano que faz, há tanto a situação humorística, quanto a dramática, ambas muito bem elaboradas. Em Black is beautiful, por exemplo, o humor se revela na inversão de um estória de estupro, ou pseudoestupro. Já em O capote, um dos mais belos contos do livro, a autora revela toda sua capacidade criadora, ao narrar o drama moderno da incapacidade de comunicação no dia-a-dia entre as pessoas, mais especificamente entre pai e filhos, que necessitam de um objeto mediador, no caso um capote, que dá origem ao título.

Com segurança no manejo das palavras, essa hermeneuta do cotidiano possui certamente excelentes predicados para figurar entre os principais autores de uma nova geração da literatura brasileira, da qual fazem parte Cristóvão Tezza, Paulo Lins, Raimundo Caruso, entre outros. 